\title{
Cord Blood Banking and Transplantation in China: A Ten Years Experience of a Single Public Bank
}

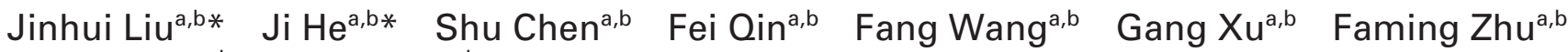 \\ Hangjun Lv $v^{a, b}$ Lixing Yan ${ }^{a, b}$ \\ a Blood Center of Zhejiang Province, \\ ${ }^{\mathrm{b}}$ Key Laboratory of Blood Safety Research, Ministry of Health, Hangzhou, Zhejiang, People's Republic of China
}

\section{Keywords}

Umbilical cord blood · Cryopreservation - Transplantation

\section{Summary}

Background: Umbilical cord blood (UCB) has successfully used for transplantation to treat hematologic malignancies and genetic diseases. Herein, we describe the experience generated in a single public UCB bank at Zhejiang Province in China. Methods: Good manufacturing practice and standard operating procedures were used to address donor selection as well as UCB collection, processing, and cryopreservation. Total nucleated cells (TNCs), cellular viability, CD34+ cells, and colonyforming units were determined, and infectious diseases screening test, sterility test, and HLA typing for UCB units were done. Results: Only $18.51 \%$ of all collected UCB units met storage criteria, and 7,056 UCB units were cryopreserved in 10 years. The volume of UCB units was $95.0 \pm 22.0 \mathrm{ml}$. The number of TNCs before and after processing was $13.32 \pm 3.63 \times 10^{8}$ and $10.63 \pm$ $2.80 \times 10^{8}$, respectively, and the recovery rate was 80.71 $\pm 11.26 \% .0 .4344 \pm 0.1874 \%$ of the TNCs were CD34+ cells. The CFU-GM was $32.1 \pm 28.0$ colonies per $1 \times 10^{5}$ nucleated cells. Based mainly on HLA and nucleated cell content, 26 UCB units were released for transplantation. Conclusions A public UCB bank was successfully established in China; collection and processing of UCB units should be optimized in order to gain maximum volume and cell count.

\footnotetext{
*Jinhui Liu and Ji He had equally contributed to the manuscript.
}

\section{KARGER \\ Fax +497614520714 \\ Information@Karger.de}

www.karger.com (c) 2012 S. Karger GmbH, Freiburg

$1660-3796 / 12 / 0391-0023 \$ 38.00 / 0$

Accessible online at:

www.karger.com/tmh

\section{Schlüsselwörter}

Nabelschnurblut $\cdot$ Kryokonservierung $\cdot$ Transplantation

\section{Zusammenfassung}

Hintergrund: Nabelschnurblut wird mit Erfolg transplantiert, um hämatologische und genetisch bedingte Erkrankungen zu behandeln. In dieser Arbeit werden die Erfahrungen einer einzelnen öffentlichen Nabelschnurblutbank in der Zhejiang-Provinz in China beschrieben. Methoden: Good Manufacturing Practice und Standard Operating Procedures kamen bei der Spenderselektion wie auch bei der Nabelschnurblutentnahme, -verarbeitung und -kryokonservierung zum Einsatz. Die Gesamtzahl kernhaltiger Zellen (total nucleated cells; TNCs), die zelluläre Viabilität, die Anzahl der CD34+ Zellen und der Kolonie bildenden Einheiten wurden bestimmt und folgende Tests durchgeführt: Screening-Test auf infektiöse Erkrankungen, Sterilitätstest und HLA-Typisierung. Ergebnisse: Nur $18,51 \%$ aller gesammelten Nabelschnurblut-Einheiten erfüllten die Lagerungsbedingen, und 7056 Einheiten wurden kryokonserviert in 10 Jahren. Das mittlere Volumen der Nabelschnurblut-Einheiten betrug $95,0 \pm 22,0 \mathrm{ml}$. Die Anzahl der TNCs vor bzw. nach der Prozessierung war $13,32 \pm 3,63 \times 10^{8}$ bzw. 10,63 $\pm 2,80 \times$ $10^{8}$, und die Rückgewinnungsrate betrug $80,71 \pm 11,26 \%$. $0,4344 \pm 0,1874 \%$ der TNCs waren CD34+ Zellen. Der CFU-GM war $32,1 \pm 28,0$ Kolonien pro $1 \times 10^{5}$ kernhaltiger Zellen. 26 Nabelschnurblut-Einheiten wurden, im Wesentlichen basierend auf HLA und Gehalt an kernhaltigen Zellen, zur Transplantation freigegeben. Schlussfolgerung: In China wurde eine öffentliche Nabelschnurblutbank erfolgreich etabliert, allerdings sollten Sammlung und Prozessierung der Nabelschnurblut-Einheiten optimiert werden, um das größte Volumen und die höchste Zellzahl zu erzielen. 


\section{Introduction}

Allogeneic hematopoietic stem cell transplantation (HSCT) is the elective treatment for a wide variety of disorders including leukemia, bone marrow failure syndromes, immunodeficiencies and inborn errors of metabolism, but relies on the presence of an appropriate donor $[1,2]$. Currently, the treatment of choice, if no suitable sibling donor is available, is a human leukocyte antigen(HLA)-matched, volunteer, unrelated donor. However, many patients cannot find a suitably matched donor in bone marrow donor registries. Therefore, umbilical cord blood (UCB) is increasingly used as an alternative source of stem cells for HSCT in patients for whom a matched bone marrow or peripheral blood donor could not be find in the past [3-6].

UCB contains stem and progenitor cells capable of restoring hematopoietic and immunological function in vivo; it can easily be harvested and stored in frozen aliquots in a UCB bank. Use of UCB for hematopoietic progenitor cell transplantation offered some benefits such as decreased incidence of graft-versus-host disease, reduced HLA matching requirements, and decreased search time since UCB units are banked and already HLA-typed. Patients with rare HLA types are often successful in finding a suitable cord graft when other sources are not acceptable. The first public UCB bank was established in 1993 by Rubinstein et al. [7] in New York, allowing unrelated UCB transplantation to become an option for patients lacking a suitable adult donor. Currently, approximately 400,000 UCB units are stored in more than $50 \mathrm{UCB}$ banks worldwide, and more than 20,000 allogeneic cord blood transplantations have been performed [8-13]. In China, there are at least seven established UCB banks, with three being planned at present. Most of them were mainly occupied with the private banking, and their experiences with UCB banking were rarely reported. We have established a single public UCB bank in the Zhejiang province in May 2001 and cryopreserved more than 7,000 UCB units up to now. Here we describe our experiences with the processing and cryopreservation of these UCB units.

\section{Material and Methods}

\section{Collection of $U C B$}

The UCB units were donated between May 2001 and February 2011; the donations came from five hospitals in the Zhejiang province, which is located in the East of China. As careful donor selection had to be performed, a detailed medical history of the family was mandatory in order to minimize the potential risk of transmitting unrecognized hereditary diseases. Written informed consent was obtained from all potential donors. The mothers filled in a registration form and were interviewed by doctors prior to delivery regarding their and their families' health issue. If a mother was diagnosed with genetic disease in her family or if there was any evidence of severe disabilities or diseases in the unborn child, she should be excluded from UCB donation. Further major exclusion criteria were infectious diseases of the mother that may be transmitted to the child, severe complications during pregnancy, premature delivery, dystrophia, or perinatal asphyxia.

The UCB collections were performed by trained staff at the Department of Obstetrics. After careful disinfection of the umbilical cord, a 16gauge needle was inserted into the umbilical vein of the delivered placenta and cord blood was drained by gravity into a triple bag system which contained $50 \mathrm{ml}$ ACD-B as anticoagulant (TianHe, Jiaxing, Zhejiang, China). After the collection process (requiring only a few minutes), a detailed documentation and labeling of the UCB unit had been performed before it was stored in a secure temperature-controlled refrigerator and subsequently transported to the UCB bank by courier. The temperature of storage and transport was at $4 \pm 2{ }^{\circ} \mathrm{C}$.

\section{Testing of $U C B$}

Each UCB unit was analyzed for volume, total nucleated cells (TNCs), CD34+ cells count, colony-forming units (CFUs), HLA class I/II antigens, $\mathrm{ABO} /$ Rhesus blood group, and bacterial contamination. The donated blood sample of the donor was tested for hepatitis B surface antigen (HBsAg), hepatitis C virus antibody (anti-HCV), human immunodeficiency virus antibody (anti-HIV), Treponema pallidum antibody (anti$\mathrm{TP}$ ), alanine aminotransferase (ALT) and $\mathrm{ABO} / \mathrm{RhD}$ blood group using different approved test kits according to the manufacturer's instruction. The number of TNCs was determined using a hematology analyzer (CellDyn ${ }^{\circledR} 1700$; Abbott S.A., Shanghai, China). Enumeration of CD34+ cells was done according to the manufacturer's instructions using BD Procount Progenitor Cell Enumeration Kit (Becton Dickinson Medical Devices Shanghai Co Ltd, Shanghai, China) and a FacsCalibur flow cytometer. Determination of CFU was performed using commercial reagents (Stem Cell Technologies, Vancouver, BC, Canada). In brief, MNCs $\left(1 \times 10^{5}\right)$ were resuspended in $1 \mathrm{ml}$ methylcellulose medium and cultured in a plastic $35 \mathrm{~mm}$ tissue culture dish for 14 days at $37{ }^{\circ} \mathrm{C}$ in an atmosphere of $5 \%$ $\mathrm{CO}_{2}$. CFU-GM was counted according to color, size, and marginal shape. For sterility test, $10 \mathrm{ml}$ of remaining RBC layer after processing was injected into test flasks for aerobic and anaerobic incubation; after incubation, the samples were evaluated using the BacT Alert/3D Signature ${ }^{\mathrm{TM}}$ system (Organon Teknika, Biomerieux Inc. Durham, NC, USA) according to manufacturer's instruction. HLA typing was performed by using a high resolution PCR-SSOP method according to the manufacturer's instruction (Orchid Lifematch; Orchid Cellmark Inc., Princeton, NJ, USA).

\section{Preparation of $U C B$}

After inspection for the appearance and characteristic of the blood bags, the UCB was weighed and the nucleated cells were counted, Units below $60 \mathrm{ml}$ or containing $<10.0 \times 10^{8} \mathrm{TNCs}$ were excluded. The hematopoietic stem cells were processed by sedimentation and centrifugation method. Briefly, hetastarch (HES) in $0.9 \%$ sodium chloride solution (Baxter Healthcare Corporation, Waukegan, IL, USA) was added into the primary bag at ratio of 1:4 (total volume of the anticoagulant:cord blood). The final concentration of HES was $1.2 \%(\mathrm{v} / \mathrm{v})$. Then reversed sedimentation at room temperature was done for 40-60 min, afterwards the layer of erythrocyte at the bottom was transferred to the satellite bag. The rest, including the leukocyte-rich layer and plasma, was centrifuged at $400 \times g$ at $10{ }^{\circ} \mathrm{C}$ for $10 \mathrm{~min}$. Excess plasma was transferred to the other satellite bag. The final leukocyte-rich layer was transferred to the freezing bag (Baxter Healthcare Corporation).

Cryopreservation solution composed of dimethyl sulfoxide $50 \%$ (Bioniche Teo Inverin Co., Galway, Ireland) and dextran 40 (KeLun, SiChuan, China) was slowly added to the processed cord blood as described by Rubinstein and colleagues [7]. The final concentration of DMSO was $10 \%(\mathrm{v} / \mathrm{v})$. Then the freezing bag was sealed and placed in an aluminum canister and freezed using a controlled-rate freezer (Kryo 550-16, PLANER, Sunbury, Middlesex, UK). The freeze parameter was $-1{ }^{\circ} \mathrm{C} /$ min from $4{ }^{\circ} \mathrm{C}$ to $-40{ }^{\circ} \mathrm{C}$ and hold $3 \mathrm{~min}$, then at $-5{ }^{\circ} \mathrm{C} / \mathrm{min}$ to $-80{ }^{\circ} \mathrm{C}$. After cooling, the UCB unit was stored in the deep-freezer with liquid nitrogen for long-term storage. 
For transplantation, the cryopreserved UCB unit was lifted to the gas phase of liquid nitrogen for $15 \mathrm{~min}$; then it was immersed in $37^{\circ} \mathrm{C}$ water bath for thawing within $2 \mathrm{~min}$. UCB was immediately infused into the HLA-matched patient for transplantation. Short tandem repeat (STR) technique was performed to confirm engraftment.

\section{Results}

\section{UCB Collection and Pre-Processing}

A total of 38,128 UCBs donations were collected. 31,072 UCBs were excluded for various reasons (table 1), and 7,056 UCBs units were cryopreserved. Only $18.51 \%$ of all UCB units were finally stored at the UCB bank.

\section{Volume Collected and Test}

The mean volume of UCB units for processing was $95.0 \pm$ $22.0 \mathrm{ml}$. The volume after processing was reduced to $23.1 \pm$ $4.3 \mathrm{ml}$ (table 2). The number of TNCs of UCB before and after processing was $13.32 \pm 3.63 \times 10^{8}$ and $10.63 \pm 2.80 \times 10^{8}$ per unit, respectively, and the recovery rate was $80.71 \pm$ $11.26 \%$. The rate of CD34+ cells was $0.4344 \pm 0.1874 \%$ before cryopreservation, and the count of CD34+ cells was $151.89 \pm 100.27 \times 10^{5} /$ unit. The CFU-GM amounted to $32.1 \pm$ 28.0 colonies per $1 \times 10^{5}$ TNCs.

\section{Infectious Diseases Testing and Sterility Testing}

63 of 7,056 UCBs units $(0.89 \%)$ were positive in the infectious diseases testing. The positive rates of hepatitis B surface antigen, anti-HCV, anti-HIV1/2 and anti-TP were $0.13 \%$ $(9 / 7,056), \quad 0.30 \%(21 / 7,056), 0.13 \%(9 / 7,056)$ and $0.34 \%$ $(24 / 7,056)$, respectively. 215 of 7,056 UCB units $(3.05 \%)$ were positive in the sterility testing. The rates of aerobic, anaerobic and eumycete infection were $1.77 \%(125 / 7,056), 1.16 \%$ $(82 / 7,056)$ and $0.11 \%(8 / 7,056)$, respectively.

\section{HLA Typing}

A total of 17 HLA-A alleles, 31 HLA-B alleles and 13 DRB1 alleles were identified in the UCB bank of Zhejiang province. The most frequent alleles included $A * 02, A * 11, A * 24, A * 33$, $\mathrm{B} * 40, \mathrm{~B} * 15, \mathrm{~B} * 46, \mathrm{~B} * 13, \mathrm{~B} * 58, \mathrm{~B} * 51, \mathrm{DRB} 1 * 09, \mathrm{DRB} 1 * 12$, DRB1*04, DRB1*15, DRB1*08, DRB1*11, DRB1*07, DRB1*14, and DRB1*03 (table 3).

\section{Transplantation}

$26 \mathrm{UCB}$ units have been released for 20 transplantation cases since 2001. All transplantation hospitals were located in China. 14 patients received a single unit, whereas 6 patients received two units. Three recipients were not evaluated because of early infection and death less than 10 days after transplantation. Stem cell engraftment was successful in 14 recipients, 7 of whom had myeloid leukemia, 5 lymphoid leukemia, 1 non-Hodgkin's lymphoma, and 1 Wiskott-Aldrich syndrome. The rate of engraftment was $82.3 \%$.
Table 1. Reasons for the exclusion of collected UCB units

\begin{tabular}{lrr}
\hline & $\mathrm{n}$ & \multicolumn{1}{c}{$\%$} \\
\hline Low volume $(<60 \mathrm{ml})$ & 18,034 & 47.30 \\
Low number of TNCs $\left(<10.0 \times 10^{8}\right)$ & 11,875 & 31.15 \\
Clot & 672 & 1.76 \\
Exceed the time $(>24 \mathrm{~h})$ & 269 & 0.70 \\
Broken bag & 142 & 0.37 \\
Abnormal result of the mother & 49 & 0.13 \\
Hemolysis of cord blood & 31 & 0.08 \\
\cline { 2 - 3 } Total & 31,072 & 81.49 \\
\hline
\end{tabular}

Table 2. Results of 7,056 cryopreservation UCB units

\begin{tabular}{lcc}
\hline & Mean & SD \\
\hline Volume collected, ml & 95.0 & 22.0 \\
Volume after processing, ml & 23.1 & 4.3 \\
TNCs before processing $\times 10^{8} /$ unit & 13.32 & 3.63 \\
TNCs after processing $\times 10^{8} /$ unit & 10.63 & 2.80 \\
Recovery rate of TNCs, \% & 80.71 & 11.26 \\
CD34+ cells $\times 10^{5} /$ unit & 151.89 & 100.27 \\
Rate of CD34+/CD45+ cells, \% & 0.4344 & 0.1874 \\
CFU-GM per $1 \times 10^{5} \mathrm{NC}$ & 32.1 & 28.0 \\
\hline
\end{tabular}

Table 3. Frequencies of the major HLA alleles

\begin{tabular}{ll|ll|lr}
\hline HLA-A & $\%$ & HLA-B* & $\%$ & HLA-DRB1 & $\%$ \\
\hline $33: X X$ & 8.25 & $51: X X$ & 6.62 & $03: X X$ & 5.25 \\
24:XX & 17.76 & $58: X X$ & 7.14 & $14: X X$ & 5.56 \\
11:XX & 27.08 & $13: X X$ & 8.86 & $07: X X$ & 6.33 \\
$02: X X$ & 31.62 & $46: X X$ & 11.76 & $11: X X$ & 7.09 \\
& & $15: X X$ & 14.58 & $08: X X$ & 9.02 \\
& & $40: X X$ & 19.45 & $15: X X$ & 11.63 \\
& & & & $04: X X$ & 12.41 \\
& & & & $12: X X$ & 14.59 \\
& & & & $09: X X$ & 18.38 \\
\hline
\end{tabular}

The majority of recipients were under 12.7 years old (range $2-39$ years) and weighed $<29.1 \mathrm{~kg}$ (range $12-73 \mathrm{~kg}$ ). The median number of TNCs infused per patient was $4.30 \times 10^{7} / \mathrm{kg}$ (range 1.11-10.19 $\times 10^{7} / \mathrm{kg}$ ). Median time to achieve an absolute neutrophil count equal to or greater than $5 \times 10^{8} / 1$ (first of 3 consecutive laboratory measurements on different days) was 18.4 days (range 12-28 days). The time to achieve an absolute platelet count equal to or greater than $5 \times 10^{10} / 1$ (first of 7 days without transfusion support) was 33.2 days (range 21-51 days).

HLA match according to HLA high-resolution typing was six of six in 8 cases $(30.8 \%)$, five of six in 13 cases $(50 \%)$, and four of six in 5 cases $(19.2 \%)$.

\section{Discussion}

UCB is a clinically useful source of hematopoietic stem and progenitor cells for treatment of a wide variety of genetic, he- 
matologic, immunologic, metabolic, and oncologic disorders [16-18]. Amongst the benefits of UCB, compared to bone marrow and mobilized peripheral blood, as a source of engrafting hematopoietic stem cells and progenitor cells are its ready availability through UCB banks and a relatively low level of graft-versus-host disease elicited by transplantation $[19,20]$. For these reasons, cryopreserved UCB banks are being established in many countries.

Selection of donors is an essential step and affects the quality of UCBs. Donor selection criteria used at our bank were very similar to those used by the Guangzhou group and other international organization $[14,21,22]$. As our data confirm, the eligibility of collected UCB is often limited by little volume and small NC count $[7,23,24]$. To achieve good quality of UCB for transplantation, over $80 \%$ of the UCB units were excluded in our bank during past decade, a rate similar to that of the Mannheim cord blood bank [32]. Nakagewa et al. [25] reported that the volume was strongly correlated to the quality of the UCBs, and the collection volume was a very important parameter for evaluating a successful UCB collection [26]. The volume is influenced by a number of obstetric factors and can be increased by improving obstetric practice. Therefore, continuous training of the collecting staff is essential to maximize the volume of UCB. It is necessary to discuss the problems emerging in the collaboration between the hospital staff and the UCB bank and resolve them in time.

A UCB unit which is considered for transplant may not only have been collected, tested, processed and stored in a different country but also may have been banked up for a decade or even longer. The quality of the product is reliant on both the procedures and processes at that time and the subsequent maintenance of proper storage conditions [27]. Reducing the volume of the UCB units by eliminating red blood cell bulk and plasma offers pragmatic advantages of convenience, efficiency, and cost $[28,29]$. We used a closed system to deplete red blood cells and plasma; the median volume and TNC content were similar to those of earlier studies, e.g. Guerra-Marquez et al. [30] and Yang et al. [31], or even higher, e.g. Lauber et al. [32] (Mannheim Cord Blood Bank). The recovery rate of TNCs was similar to that reported by Solves et al. [33] at the Valencia Cord Blood Bank in Spain.
Interestingly, a comparably low bacterial contamination was found; we assumed that a thorough cleaning and disinfection protocol of the cord could explain these results. We also found a low positive rate of transmitted infection agents, which may due to the restricted donor selection.

UCB transplantation has become a first-line therapy for specific hematologic conditions, particularly in pediatric patients [34]. It is noteworthy, however, that during the past decade its application has expanded to adult patients by using large single-unit or double-unit transplants. Indeed, according to the inventory reported by NETCORD on February, 2011, the mean consumption rate among registered UCB blood banks was $4.58 \%$. In our bank UCB bank, a total of 26 UCB units have been released for transplantation, which represents $0.37 \%$ of the total number of stored units. The consumption rate was similar to that of the UCB bank in Athens $(0.35 \%)$ and was lower than those of the UCB banks in Barcelona (4.67\%), New York (6.59\%), and Tokyo (6.21\%) [30]. Although our UCB units were mainly used for children, our data also confirmed that main indications for UCB transplantations were malignant diseases.

In summary, with the processing techniques used for routine banking about 7,000 samples shows a high and consistent recovery rate of TNCs and high quality, which is extremely important for UCB banking. Although the experience presented herein is still limited, the results obtained during this period are encouraging and indicate that the UCB banking and transplantation program will help to improve already existing hematopoietic cell transplant programs.

\section{Acknowledgements}

This material is based upon work funded by Zhejiang Provincial Program for the Cultivation of High-Level Innovative Health Talents and Science Research Foundation of Zhejiang Healthy Bureau (2011RCA018, 2010KYB033, 2009A046).

\section{Disclosure Statement}

The authors declared no conflict of interest.

\section{References}

1 Hurley CK, Raffoux C: World Marrow Donor Association: international standards for unrelated hematopoietic stem cell donor registries. Bone Marrow Transplant 2004;34:103-110.

2 Hurley CK, Foeken L, Horowitz M, Lindberg B, McGregor M, Sacchi N, WMDA Accreditation and Regulatory Committees: Standards, regulations and accreditation for registries involved in the worldwide exchange of hematopoietic stem cell donors and products. Bone Marrow Transplant 2010;45:819-824.
3 Wernet PW: The international NETCORD foundation; in Broxmeyer HE (ed): Cord Blood: Biology, Immunology, Banking and Clinical Transplantation. Bethesda, AABB Press, 2004, pp 429-435.

4 Eapen M, Rubinstein P, Zhang MJ, Stevens C, Kurtzberg J, Scaradavou A, Loberiza FR, Champlin RE, Klein JP, Horowitz MM, Wagner JE: Outcomes of transplantation of unrelated donor umbilical cord blood and bone marrow in children with acute leukaemia: a comparison study. Lancet 2007;369:1947-1954.

\footnotetext{
5 Kurtzberg J, Prasad VK, Carter SL, Wagner JE, Baxter-Lowe LA, Wall D, Kapoor N, Guinan EC, Feig SA, Wagner EL, Kernan NA, COBLT Steering Committee: Results of the Cord Blood Transplantation Study (COBLT): clinical outcomes of unrelated donor umbilical cord blood transplantation in pediatric patients with hematologic malignancies. Blood 2008;112:4318-4327.
} 
6 Wagner JE, Barker JN, DeFor TE, Baker KS, Blazar BR, Eide C, Goldman A, Kersey J, Krivit W, MacMillan ML, Orchard PJ, Peters C, Weisdorf DJ, Ramsay NK, Davies SM: Transplantation of unrelated donor umbilical cord blood in 102 patients with malignant and nonmalignant diseases: influence of CD34 cell dose and HLA disparity on treatment related mortality and survival. Blood 2002;100:1611-1618.

7 Rubinstein P, Dobrila L, Richard E, Rosenfield RE, Adamson JW, Migliaccio G, Migliaccio AR, Taylor PE, Stevens CE: Processing and cryopreservation of placental/umbilical cord blood for unrelated bone marrow reconstitution. Proc Natl Acad Sci U S A 1995;92:10119-10122.

8 Navarrete C, Contreras M: Cord blood banking: a historical perspective. Br J Haematol 2009;147:236245.

9 Kurtzberg J, Cairo MS, Fraser JK, Baxter-Lowe L, Cohen G, Carter SL, Kernan NA: Results of the cord blood transplantation (COBLT) study unrelated donor banking program. Transfusion 2005;45: 842-855.

-10 Gluckman E, Rocha V: Cord blood transplantation: state of the art. Haematologica 2009;94:536-541.

11 Foeken LM, Green A, Hurley CK, Marry E, Wiegand T, Oudshoorn M; Donor Registries Working Group of the World Marrow Donor Association (WMDA): Monitoring the international use of unrelated donors for transplantation: the WMDA annual reports. Bone Marrow Transplant 2010;45: 811-818.

12 Gluckman E: History of cord blood transplantation. Bone Marrow Transplant 2009;44:621-626.

13 Rocha V, Kabbara N, Ionescu I, Ruggeri A, Purtil D, Gluckman E: Pediatric related and unrelated cord blood transplantation for malignant diseases. Bone Marrow Transplant 2009;44:653-659.

- 14 Wu JY, Liao C, Xu ZP, Chen JS, Gu SL, Huang YN, Li Y, Tang XW, Yang X, Tang PH, Tsang KS: Banking and transplantation of umbilical cord blood in Guangzhou, China. Cytotherapy 2006;8:488-497.

15 Liu JH, He J, Zhu FM, Yan LX: Processing and cryopreservation for 1963 units of human umbilical cord blood. J Exp Hematol 2005;13:143-146.

16 Rocha V, Cornish J, Sievers EL, Flipovich A Locatelli F, Peters C, Remberger M, Michel G, Arcese W, Dallorso S, Tiedemann K, Busca A, Chan KW, Kato S, Ortega J, Vowels M, Zander A, Souillet G, Oakill A, Woolfrey A, Pay AL, Green A, Garnier F, Ionescu I, Gluckman E: Comparisons of outcomes of unrelated bone marrow and umbilical cord blood transplants in children with acute leukaemia. Blood 2001;97:2962-2971.
17 Smith FO, Thomson BG: Umbilical cord blood collection, banking, and transplantation: current status and issues relevant to perinatal caregivers. Birth 2000;27:127-135.

18 Ballen KK: New trends in umbilical cord blood transplantation. Blood 2005; 105:3786-3792.

19 Gluckman E: Current status of umbilical cord blood hematopoietic stem cell transplantation. Exp Hematol 2000;28:1197-1205.

20 Wadlow RC, Porter DL: Umbilical cord blood transplantation: where do we stand? Biol Blood Marrow Transplant 2002;8:637-647.

21 Mancinelli F, Tamburini A, Spagnoli A, Malerba C, Suppo G, Lasorella R, de Fabritiis P, Calugi A: Optimizing umbilical cord blood collection: impact of obstetric factors versus quality of cord blood units. Transplant Proc 2006;38:1174-1176.

22 Urciuoli P, Passeri S, Ceccarelli F, Luchetti B, Paolicchi A, Lapi S, Nocchi F, Lamanna R, Iorio M, Vanacore R, Mazzoni A, Scatena F: Pre-birth selection of umbilical cord blood donors. Blood Transfus 2010;8:36-43.

23 Gluckman E, Rocha V, Arcese W, Michel G, Sanz G, Chan KW, Takahashi TA, Ortega J, Filipovich A, Locatelli F, Asano S, Fagioli F, Vowels M, Sirvent A, Laporte JP, Tiedemann K, Amadori S, Abecassis M, Bordigoni P, Diez B, Shaw PJ, Vora A, Caniglia M, Garnier F, Chevret S, Eurocord Group: Factors associated with outcomes of unrelated cord blood transplant: guidelines for donor choice. Exp Hematol 2004;32:397-407.

24 Wagner JE, Barker JN, DeFor TE, Baker KS, Blazar BR, Eide C, Goldman A, Kersey J, Krivit W, MacMillan ML, Orchard PJ, Peters C, Weisdorf DJ, Ramsay NK, Davies SM: Transplantation of unrelated donor umbilical cord blood in 102 patients with malignant and nonmalignant diseases: influence of CD34 cell dose and HLA disparity on treatment related mortality and survival. Blood 2002;100:1611-1618.

25 Nakagawa R, Watanabe T, Kawano Y, Kanai S, Suzuya H, Kaneko M, Watanabe H, Okamoto Y, Kuroda Y, Nakayama T, Chugoku-Shikoku Cord Blood Bank: Analysis of maternal and neonatal factors that influence the nucleated and CD34+ cell yield for cord blood banking. Transfusion 2004;44: 262-267.
6 Lecchi L, Perego L, Garcea F, Ratti I, Brasca M, Dotti D, Cimoni S, Pezzali I, Celeste T, Giovanelli S, Butti B, De Fazio N, Lopa R, Rebulla P: Tenyear quality control of a semiautomated procedure of cord blood unit volume reduction. Transfusion 2009;49:563-569.

27 Lasky LA, Lane TA, Miller JP, Lindgren B, Patterson HA, Haley NR, Ballen K: In utero or ex utero cord blood collection: which is better? Transfusion 2002;42:1261-1267.

28 Hongyou Yang, Acker JP, Abley D, McGann LE, Akabutu J: High efficiency volume reduction of cord blood using pentastarch. Bone Marrow Transplant 2001;27:457-461.

29 Solves P, Mirabet V, Blanquer A, Delgado-Rosas F, Planelles D, Andrade M, Carbonell-Uberos F, Soler MA, Roig R: A new automatic device for routine cord blood banking: critical analysis of different volume reduction methodologies. Cytotherapy 2009;11:1101-1107.

30 Guerra-Marquez A, Novelo-Garza B, MalagónMartínez A, Limon-Flores A, Luna-Bautista F, Juan-Shum L, Montero-Ponce I, Sanchez-Valle E, Peñaflor K, Vélez-Ruelas MA, Romero-Juárez Y, Mayani H: Cord blood banking and transplantation at the Mexican Institute of Social Security: the first 5 years. Transfusion 2011;51:328-332.

31 Yang H, Loutfy MR, Mayerhofer S, Shuen P: Factors affecting banking quality of umbilical cord blood for transplantation. Transfusion 2011;51:284 292.

32 Lauber S, Latta M, Klüter H, Müller-Steinhardt M: The Mannheim Cord Blood Bank: experiences and perspectives for the future. Transfus Med Hemother 2010;37:90-97.

33 Solves P, Mirabet V, Blanquer A, Delgado-Rosas F, Planelles D, Andrade M, Carbonell-Uberos F, Soler MA, Roig R: A new automatic device for routine cord blood banking: critical analysis of different volume reduction methodologies. Cytotherapy 2009;11:1101-1107.

34 Rocha V,Gluckman E: Improving outcomes of cord blood transplantation: HLA matching, cell dose and other graft- and transplantation-related factors. Br J Haematol 2009;147:262-274. 